\title{
Article \\ Effects of Chitosan and Duck Fat-Based Emulsion Coatings on the Quality Characteristics of Chicken Meat during Storage
}

\author{
Dong-Min Shin (D, Yea-Ji Kim, Jong-Hyeok Yune, Do-Hyun Kim, Hyuk-Cheol Kwon (D), Hyejin Sohn, Seo-Gu Han, \\ Jong-Hyeon Han $\mathbb{D}$, Su-Jin Lim and Sung-Gu Han*(D)
}

check for updates

Citation: Shin, D.-M.; Kim, Y.-J.; Yune, J.-H.; Kim, D.-H.; Kwon, H.-C.; Sohn, H.; Han, S.-G.; Han, J.-H.; Lim, S.-J.; Han, S.-G. Effects of Chitosan and Duck Fat-Based Emulsion Coatings on the Quality Characteristics of Chicken Meat during Storage. Foods 2022, 11, 245 https://doi.org/10.3390/

foods11020245

Academic Editors:

Theodoros Varzakas and Rui M. S. Cruz

Received: 22 December 2021

Accepted: 15 January 2022

Published: 17 January 2022

Publisher's Note: MDPI stays neutral with regard to jurisdictional claims in published maps and institutional affiliations.

Copyright: (C) 2022 by the authors. Licensee MDPI, Basel, Switzerland. This article is an open access article distributed under the terms and conditions of the Creative Commons Attribution (CC BY) license (https:// creativecommons.org/licenses/by/ $4.0 /)$
Department of Food Science and Biotechnology of Animal Resources, Konkuk University, Seoul 05029, Korea; jeff.shin90@gmail.com (D.-M.S.); dpw1961113@konkuk.ac.kr (Y.-J.K.); skyun0423@konkuk.ac.kr (J.-H.Y.); secret311@konkuk.ac.kr (D.-H.K.); rnjs1024@konkuk.ac.kr (H.-C.K.); sonhjin123@konkuk.ac.kr (H.S.); tjrn8854@konkuk.ac.kr (S.-G.H.); hyeon4970@konkuk.ac.kr (J.-H.H.); tnwlsdl1110@konkuk.ac.kr (S.-J.L.)

* Correspondence: hansg@konkuk.ac.kr

\begin{abstract}
Chicken meat is a popular food commodity that is widely consumed worldwide. However, the shelf-life or quality maintenance of chicken meat is a major concern for industries because of spoilage by microbial growth. The aim of this study was to evaluate the effects of chitosan and duck fat-based emulsion coatings on the quality characteristics and microbial stability of chicken meat during refrigerated storage. The coated chicken meat samples were as follows: control (non-coated), DFC0 (coated with duck fat), DFC0.5 (coated with duck fat and 0.5\% chitosan), DFC1 (coated with duck fat and $1 \%$ chitosan), DFC2 (coated with duck fat and $2 \%$ chitosan), and SOC2 (coated with soybean oil and $2 \%$ chitosan). The results showed that the apparent viscosity and coating rate were higher in DFC2 than in other groups. Physicochemical parameters ( $\mathrm{pH}$, color, and Warner-Bratzler shear force) were better in DFC2 than those in other groups during 15 days of storage. Moreover, DFC2 delayed lipid oxidation, protein deterioration, and growth of microorganisms during storage. These data suggest that chitosan-supplemented duck fat-based emulsion coating could be used to maintain the quality of raw chicken meat during refrigerated storage.
\end{abstract}

Keywords: duck fat; chitosan; edible coating; chicken meat; shelf-life

\section{Introduction}

The consumption of chicken meat has increased over recent decades because of its low-cost, low-fat content, high nutritional value, and unique flavor [1]. However, chicken meat is a perishable product because it enables the growth of spoilage and pathogenic microorganisms [2]. This is because of its high moisture and protein contents and high $\mathrm{pH}$ value. The shelf-life of chicken meat is as short as $3-5$ days in a refrigerator [3]. Hence, the chicken meat industry is interested in extending the shelf-life of raw chicken meat.

In recent years, edible coating technology has received attention for improving food quality and shelf-life. Edible emulsion coatings are described as a thin and continuous layer of edible biomaterial that may be formed or placed on or between foods [4]. These coating biomaterials are mainly derived from natural materials, including proteins (e.g., gelatin, whey, and zein), polysaccharides (e.g., chitosan and alginate), and lipids (e.g., soybean oil and sunflower oil) $[5,6]$. However, protein and polysaccharide-based coating materials are highly vulnerable to moisture and are not suitable for water-resistant coatings [7]. Among various coating materials, lipid-based edible coatings provide a better moisture barrier and protection for foods, and vegetable oils and waxes are the main components of edible coatings [6]. However, the use of vegetable oils causes lipid oxidation due to the high levels of unsaturated fatty acids, as the predominant fatty acid in vegetable oils is linoleic acid [8]. According to a previous study, sunflower oil-chitosan edible films for pork hamburgers were more vulnerable to oxidation than non-coated samples [9]. Moreover, for emulsion coatings, rheological properties, such as apparent viscosity and yield stress, are 
important for determining the coating quality [7]. Linoleic acid-rich lipid products have poorer rheological and textural properties than oleic acid-rich lipid products [10].

Duck meat is well-known for its unique flavor and aroma, and high nutritional values such as essential amino acids and unsaturated fatty acids [11]. Duck fat is usually obtained as a by-product during duck meat production [12]. Duck fat contains high levels of unsaturated fatty acids (64.51\%), including oleic acid (48.7\%) and linoleic acid (15.8\%), as well as low levels of saturated fatty acids $(28.53 \%)$ compared with other animal fats (e.g., beef fat and pork fat) [13]. Hence, duck fat intake has the potential to provide health benefits to humans by decreasing the risk of cardiovascular diseases [14,15]. In addition, unlike linoleic acid-rich oil, the presence of oleic acid in duck fat can delay lipid oxidation due to its resistance to oxidation [16]. In addition, the high oleic acid content of duck fat can provide strong physical and thermal resistance in lipid-based products [10]. Like duck fat, olive oil is also rich in oleic acid. However, olive oil is not a suitable material for manufacturing an edible coating solution due to its dark color and price, compared to other oils $[17,18]$. Considering the cost efficiency, duck fat is a cheaper source for an edible coating solution than olive oil [13].

Edible coatings are a new approach to controlling microbial growth, and thereby improve the shelf-life and safety of meat, fish, and poultry products [19]. In fact, lipid-based edible coatings are insufficient to control microorganisms, and, thus, the use of antimicrobial agents is required [9]. Chitosan is made by the deacetylation of chitin and is a versatile biopolymer. Chitosan is used as a natural preservative for edible coating manufacturing because of its strong antimicrobial properties against several foodborne microorganisms [3]. Many studies have reported that chitosan-added edible coatings can extend the shelf-life of fresh fruits and vegetables [20,21]. Additionally, chitosan-added edible coatings can be applied to fresh poultry, meat, and fish products. For example, the effects of chitosan coatings and gamma irradiation on chicken meat [22], chitosan-gelatin edible coatings with nisin and grape seed extract on fresh pork [23], chitosan coatings incorporated with lactoperoxidase on trout [24], and chitosan-soybean oil emulsion coatings on eggs [25] have been reported.

There are limited publications that provide practical and effective coating techniques for the chicken meat industry. Therefore, the objective of this study was to evaluate the effects of chitosan and duck fat-based edible coatings on the quality characteristics and microbial stability of chicken meat during refrigerated storage (at $4{ }^{\circ} \mathrm{C}$ for 15 days).

\section{Materials and Methods}

\subsection{Materials}

Chicken meat and soybean oil (SO; Beksul, Incheon, Korea) were purchased from a local market. Duck fat (DF) was kindly provided by Taekyung Nongsan (Seoul, Korea). Chitosan (molecular weight of 310-375 kDa, acid-soluble, and coarse ground flakes and powder from crustacean shells), lecithin, Tween ${ }^{\circledR} 80$ (polyoxyethylene-20 sorbitan monooleate), thiobarbituric acid (TBA), chloroform, bromocresol green, methyl red, boric acid, sulfuric acid, and acetic acid were obtained from Sigma-Aldrich Co. (St. Louis, MO, USA).

\subsection{Preparation of Coating Solution and Coating of Chicken Meat}

The edible coating solution was prepared as previously described [25]. Briefly, chitosan (final $\mathrm{pH}$ of 4.52 ) was prepared by dissolving chitosan in $1 \%$ acetic acid $(v / v)$ solution (i.e., $0.5,1.0$, and $2.0 \mathrm{~g}$ of chitosan $/ 100 \mathrm{~mL}$ acetic acid $(w / v)$ ). The chitosan solution and DF were mixed at a ratio of $40: 60$ by adding the Tween ${ }^{\circledR} 80$ emulsifier. This chitosan/DF mixture was blended for $3 \mathrm{~min}$ at low speed, followed by blending for $6 \mathrm{~min}$ at high-speed using a hand blender (Tefal Co., Ltd., Mayenne, France). The mixture was homogenized at 20,000 rpm for 3 min using a homogenizer (DAIHAN Scientific Co., Ltd., Gangwon, Korea).

To coat the chicken meat, the meat samples were immersed in the coating solution for $2 \mathrm{~min}$ under magnetic stirring at $800 \mathrm{rpm}$. Samples were then placed in a biological hood for $2 \mathrm{~h}$ at $25 \pm 2{ }^{\circ} \mathrm{C}$ to form an edible coating. The coated sample was sealed in a 
polyethylene bag and stored at $4 \pm 1^{\circ} \mathrm{C}$. Sample analyses were performed on days $0,3,5$, 7,10 , and 15 of refrigerated storage. The total number of chicken breast meat slices used for physicochemical and microbiological analyses was 288. The control and treatment groups were prepared as follows: control (NC, non-coated), DFC0 (coated with duck fat), DFC0.5 (coated with duck fat and $0.5 \%$ chitosan), DFC1 (coated with duck fat and 1\% chitosan), DFC2 (coated with duck fat and $2 \%$ chitosan), and SOC2 (coated with soybean oil and $2 \%$ chitosan).

\subsection{Apparent Viscosity of Coating Solution}

The apparent viscosity of the coating solution was measured using a rheometer (model MCR 92, Anton Paar, Graz, Austria) at $25^{\circ} \mathrm{C}$, and the data were collected between shear rates of 0.1 and $100 \mathrm{~Hz}(n=3$ /group). The results are expressed in units of Pascal-seconds (Pa-s). The data were analyzed using an Anton Paar RheoCompass Ver. 1.25.

\subsection{Coating Rate of Samples}

The coating rate was determined as described previously [26]. The coating rate (\%) of samples was calculated as (weight of coated chicken meat $(\mathrm{g})$-weight of raw chicken meat $(\mathrm{g}))$ / weight of coated chicken meat $(\mathrm{g}) \times 100$.

\section{5. $\mathrm{pH}$ and Color Measurements of Chicken Meat}

The $\mathrm{pH}$ of the coated chicken meat was determined using a $\mathrm{pH}$ meter (LAQUA, Horiba, Ltd., Kyoto, Japan). Briefly, $5 \mathrm{~g}$ of sample and $20 \mathrm{~mL}$ distilled water were homogenized at 10,000 rpm for 30 s using a homogenizer (DAIHAN Scientific Co., Ltd., Gangwon, Korea), and the $\mathrm{pH}$ of the homogenate was measured. Color was measured on the surface of the coated samples using a CR-210 colorimeter (Minolta Camera Co., Ltd., Osaka, Japan) with standard white calibration plates. The data were expressed as L* (lightness), a* (redness), and $b^{*}$ (yellowness) values.

\subsection{Warner-Bratzler Shear Force (WBSF)}

The WBSF of the chicken meat was measured using a TA-XT2i texture analyzer (Stable Micro Systems Ltd., Godalming, UK) equipped with a Warner-Bratzler shear attachment (V-type blade set). Samples were cut to sizes of $2.0 \times 2.0 \mathrm{~cm}(n=8)$. The WBSF was analyzed under the following conditions: a test speed of $2.0 \mathrm{~mm} / \mathrm{s}$, a post-test speed of $4.0 \mathrm{~mm} / \mathrm{s}$, and a distance of $25.0 \mathrm{~mm}$. The maximum force required to shear through the samples was determined and analyzed as WBSF.

\subsection{Lipid Oxidation}

The lipid oxidation of coated chicken meat was evaluated by measuring the development of thiobarbituric acid reactive substances (TBARS) according to a previously described method [27]. Briefly, the coated sample (10 g) was blended with distilled water $(50 \mathrm{~mL})$, and then the mixture was homogenized for 2 min using a Model AM-7 homogenizer (Nissei Co., Ltd., Tokyo, Japan). The homogenate was transferred to a distillation flask and $47.5 \mathrm{~mL}$ of distilled water, $2.5 \mathrm{~mL}$ of $4 \mathrm{~N} \mathrm{HCl}$ solution, and $1 \mathrm{~mL}$ of antifoam agent (KMK-73, Shin-Etsu Silicone Co., Ltd., Seoul, Korea) were added to it. The mixture was distilled, and $40 \mathrm{~mL}$ of the distillate was collected. Then, $5 \mathrm{~mL}$ of the collected sample and $5 \mathrm{~mL}$ of TBA reagent $\left(0.02 \mathrm{M}\right.$ in $90 \%$ acetic acid) were mixed in a test tube and heated at $95^{\circ} \mathrm{C}$ for $30 \mathrm{~min}$. After cooling, the absorbance of the samples was measured at $538 \mathrm{~nm}$ for TBARS measurements using a UV/VIS spectrophotometer (Optizen 2120 UV Plus, Mecasys Co., Ltd., Daejeon, Korea).

\subsection{Volatile Basic Nitrogen (VBN)}

The volatile basic nitrogen (VBN, $\mathrm{mg} \%$ ) content was determined using the Conway microdiffusion method, as reported previously [28]. In brief, $5 \mathrm{~g}$ of the coated chicken meat sample was mixed with $20 \mathrm{~mL}$ of distilled water. The mixtures were homogenized at 
10,000 rpm for 1 min using a homogenizer (Model AM-7, Nihonseiki Kaisha Ltd., Tokyo, Japan) and filtered using Whatman No. 1 filter paper (Whatman International, Maidstone, UK). After filtering, $30 \mathrm{~mL}$ of distilled water was added. Then, $1 \mathrm{~mL}$ of the filtered sample and $1 \mathrm{~mL}$ of $50 \% \mathrm{~K}_{2} \mathrm{CO}_{3}$ solution were added to the outer section, and $100 \mu \mathrm{L}$ of indicator $(1: 1=0.066 \%$ bromocresol green in ethanol- $0.066 \%$ methyl red in ethanol) and $1 \mathrm{~mL}$ of $0.01 \mathrm{~N} \mathrm{H}_{3} \mathrm{BO}_{3}$ were added to the inner section of the Conway microdiffusion cells. The cells were incubated for $90 \mathrm{~min}$ at $37^{\circ} \mathrm{C}$, and the solution in the inner section was titrated with $0.02 \mathrm{~N} \mathrm{H}_{2} \mathrm{SO}_{4}$ solution.

\subsection{Microbiological Analysis}

Microbiological evaluation was performed on days $0,3,5,7,10$, and 15 of storage. Briefly, $25 \mathrm{~g}$ of coated chicken meat sample was mixed using a stomacher (Masticator Paddle Blender, IUL Instrument, Barcelona, Spain) with $225 \mathrm{~mL}$ of $0.1 \%$ peptone water for $2 \mathrm{~min}$. The mixtures were serially diluted with $0.1 \%$ peptone water. The total viable count (TVC) and Listeria spp. were counted on plate count agar (Merck, Darmstadt, Germany) and Oxford agar (Oxoid Ltd., Hampshire, UK), and each agar was incubated at $37^{\circ} \mathrm{C}$ for $24 \mathrm{~h}$. Escherichia coli, coliforms, molds, and yeasts were counted using Petrifilm (3M, St. Paul, MN, USA). E. coli and coliforms were incubated at $36^{\circ} \mathrm{C}$ for $24 \mathrm{~h}$, and molds and yeasts were incubated at $25^{\circ} \mathrm{C}$ for 5 days. The results are expressed as $\log \mathrm{CFU} / \mathrm{g}$.

\subsection{Statistical Analysis}

Each experiment was performed in triplicate and the data are expressed as mean \pm standard deviation (SD). A two-way analysis of variance (ANOVA) followed by Duncan's multiple range test $(p<0.05)$ was conducted using SPSS Ver. 24.0 (SPSS Inc., Chicago, IL, USA) for assessing significant differences.

\section{Results and Discussion}

\subsection{Apparent Viscosity of Coating Solution and Coating Rate}

The apparent viscosities of the coating solutions are shown in Figure 1A. The apparent viscosity of the coating solution was significantly affected by the type of lipid and the addition of chitosan, where DFC2 exhibited the highest apparent viscosity among the groups $(p<0.05)$. This can be explained by the melting point of duck fat. In a previous study, duck fat-added margarine had higher apparent viscosity than soybean oil-added margarine due to the higher melting point of duck fat $\left(6.21^{\circ} \mathrm{C}\right)$ than that of soybean oil $\left(-22.59^{\circ} \mathrm{C}\right)[10]$. The chitosan content also affected the apparent viscosity of the coating solution. This can be explained by the degree of chain entanglement in the coating solution. As the polymer concentration increases, the freedom of movement of polymer chains is restricted because of the correspondingly greater entanglement [29].

The coating rate of the coating solution showed trends similar to those of apparent viscosity (Figure 1B). The coating rate increased as the amount of chitosan increased in the duck fat. Duck fat had a higher coating rate than soybean oil. More specifically, the coating rate of DFC2 was higher than that of other coating solution groups $(p<0.05)$. This may be due to an increase in the apparent viscosity of the coating solution. A high viscosity of the solution can lead to a more stable shape, which leads to a higher coating yield [30]. In addition, polysaccharides, such as chitosan and dietary fiber have a high water holding capacity, which can enhance the emulsifying capacity, thereby increasing viscosity [31,32]. 
(A)

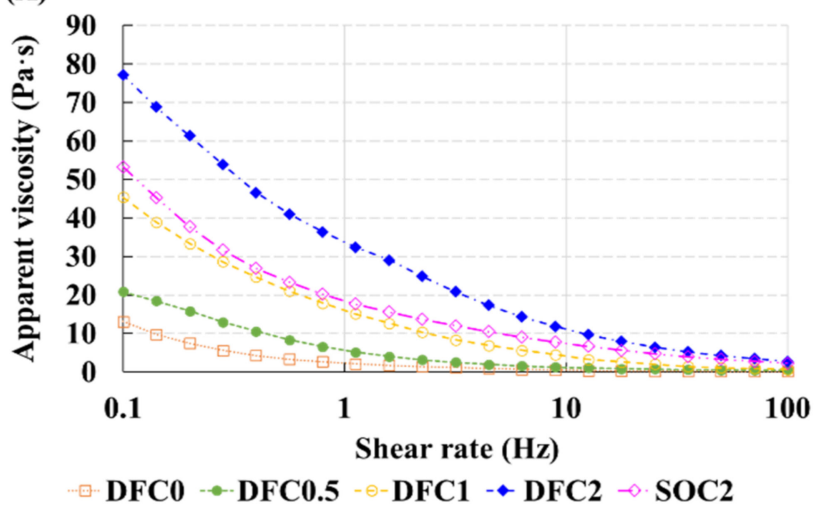

(B)

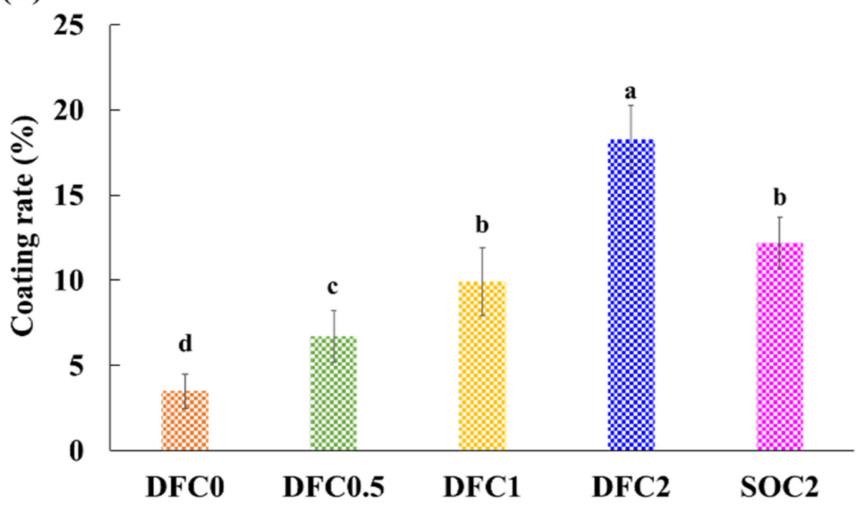

Figure 1. Apparent viscosity and coating rate of the coating solution. (A) Apparent viscosity $(n=3)$ and $(\mathbf{B})$ coating rate $(n=3)$. DFC0, coated with duck fat, with no chitosan; DFC0.5, coated with duck fat and $0.5 \%$ chitosan; DFC1, coated with duck fat and 1\% chitosan; DFC2, coated with duck fat and $2 \%$ chitosan; SOC2, coated with soybean oil and $2 \%$ chitosan. Bars with the different letter are significantly different $(p<0.05)$, and the error bars indicate SD.

\section{2. $\mathrm{pH}$ and Color of Coated Chicken Meat}

Chicken meat is more prone to rapid bacterial deterioration than pork and beef because raw chicken meat generally has a higher $\mathrm{pH}$ (0.2-0.4 higher than raw pork and beef) [33]. In addition, the changes in the $\mathrm{pH}$ values of chicken meat are highly related to microbial balance, which can lead to a low shelf-life [34]. The $\mathrm{pH}$ values of coated chicken meat during refrigerated storage are presented in Table 1 . As expected, the $\mathrm{pH}$ of all samples tended to increase with storage until day $10(p<0.05)$. This increase was significantly higher in the NC group than in other groups $(p<0.05)$. This may be due to the antimicrobial activity of chitosan in the coating solution. A previous study reported that the antibacterial properties of chitosan in coated samples were associated with the lower $\mathrm{pH}$ values of samples [35]. Moreover, when chicken meat becomes spoilt, VBN values tend to increase due to the production of $\mathrm{NH}_{3}$ along with other volatile amines [36]. Therefore, the higher $\mathrm{pH}$ of $\mathrm{NC}$ could be explained by faster spoilage than that of the coated groups.

Color is considered by consumers as the most important factor in the marketability of meat and poultry. Table 1 shows the $\mathrm{L}^{*}$ (lightness), $\mathrm{a}^{*}$ (redness), and $\mathrm{b}^{*}$ (yellowness) values of the coated chicken meat during storage. Both the storage period and the presence of coating affected the color of the samples $(p<0.05)$. The $L^{*}$ values of all samples decreased during storage $(p<0.05)$. The coated samples showed higher $L^{*}$ values than the NC group $(p<0.05)$. Using chitosan-based emulsions for the coating solution could lead to an increase in the $\mathrm{L}^{*}$ value of the samples. When the chitosan emulsion forms, the turbidity and opacity of the solution can increase, resulting in increased lightness [37]. Similar results were reported where a chitosan-essential oil solution increased the $\mathrm{L}^{*}$ value of coated chicken meat [34]. The changes in $a^{*}$ and $b^{*}$ values are highly associated with the formation of metmyoglobin, which forms by the oxygenation of myoglobin [38]. As the storage period increased, the $a^{*}$ values of all samples decreased, and $b^{*}$ values increased. $(p<0.05)$. DFC1, DFC2, and SOC2 showed higher $a^{*}$ values and lower $b^{*}$ values than the NC group during the storage period $(p<0.05)$. This was probably due to the inhibition of myoglobin oxidation by the antioxidant activity of chitosan. Cooked pork chops coated with chitosan and bamboo vinegar effectively maintain their initial $a^{*}$ and $b^{*}$ values during storage because chitosan has high antioxidant properties and can maintain meat color because of its ability to act as a chelator of transition metal ions [39]. Overall, the chitosan and duck fat-based emulsion coating may be a good option for inhibiting the discoloration of chicken meat during refrigerated storage. 
Table 1. $\mathrm{pH}$ and color of coated chicken meat during storage at $4 \pm 1{ }^{\circ} \mathrm{C}$ for up to 15 days.

\begin{tabular}{|c|c|c|c|c|c|c|c|}
\hline \multirow{2}{*}{ Parameter } & \multirow{2}{*}{ Treatment ${ }^{1)}$} & \multicolumn{6}{|c|}{ Storage Period (Days) } \\
\hline & & 0 & 3 & 5 & 7 & 10 & 15 \\
\hline \multirow{6}{*}{$\mathrm{pH}$} & $\mathrm{NC}$ & $5.99 \pm 0.01 \mathrm{Ad}$ & $5.92 \pm 0.01 \mathrm{Ae}$ & $5.98 \pm 0.02 \mathrm{Ad}$ & $6.20 \pm 0.01^{\mathrm{Aa}}$ & $6.14 \pm 0.01^{\mathrm{Ab}}$ & $6.03 \pm 0.01 \mathrm{Ac}$ \\
\hline & $\mathrm{DFC} 0$ & $5.86 \pm 0.01 \mathrm{Cd}$ & $5.86 \pm 0.03^{\mathrm{Bd}}$ & $5.92 \pm 0.01^{\mathrm{Bc}}$ & $5.85 \pm 0.01 \mathrm{Cd}$ & $6.08 \pm 0.01 \mathrm{Ba}$ & $6.00 \pm 0.01 \mathrm{Bb}$ \\
\hline & DFC0.5 & $5.88 \pm 0.01^{\mathrm{Bb}}$ & $5.90 \pm 0.01 \mathrm{Ab}$ & $5.84 \pm 0.01 \mathrm{Dc}$ & $5.92 \pm 0.01 \mathrm{Ba}$ & $5.94 \pm 0.01^{\mathrm{Da}}$ & $5.89 \pm 0.02 \mathrm{Cb}$ \\
\hline & DFC1 & $5.81 \pm 0.01^{\mathrm{Ee}}$ & $5.85 \pm 0.01^{\mathrm{Bc}}$ & $5.87 \pm 0.03 \mathrm{Cb}$ & $5.86 \pm 0.01 \mathrm{Cbc}$ & $5.90 \pm 0.01^{\mathrm{Ea}}$ & $5.81 \pm 0.01 \mathrm{Dd}$ \\
\hline & DFC2 & $5.87 \pm 0.01 \mathrm{Ccd}$ & $5.90 \pm 0.01 \mathrm{Abc}$ & $5.94 \pm 0.01$ Bab & $5.83 \pm 0.06^{\mathrm{Cd}}$ & $5.97 \pm 0.03 \mathrm{Ca}$ & $5.79 \pm 0.01 \mathrm{Ee}$ \\
\hline & SOC2 & $5.84 \pm 0.01 \mathrm{De}$ & $5.87 \pm 0.01^{\mathrm{Bcd}}$ & $5.97 \pm 0.01 \mathrm{Ab}$ & $5.85 \pm 0.02 \mathrm{Cde}$ & $5.98 \pm 0.01 \mathrm{Ca}$ & $5.88 \pm 0.01 \mathrm{Cc}$ \\
\hline \multirow{6}{*}{$\mathrm{L}^{*}$} & $\mathrm{NC}$ & $58.68 \pm 2.90^{\mathrm{Ba}}$ & $57.51 \pm 5.34^{\text {Bab }}$ & $57.46 \pm 2.38^{\text {Bab }}$ & $56.26 \pm 2.91$ Bab & $56.17 \pm 4.85^{\text {Bab }}$ & $54.79 \pm 2.61^{\mathrm{Bb}}$ \\
\hline & $\mathrm{DFC} 0$ & $62.00 \pm 3.37 \mathrm{Aa}$ & $61.17 \pm 2.48 \mathrm{Aa}$ & $60.32 \pm 3.75^{\mathrm{Aab}}$ & $58.39 \pm 2.84 \mathrm{ABbc}$ & $58.33 \pm 2.15 \mathrm{ABbc}$ & $57.34 \pm 3.09 \mathrm{Ac}$ \\
\hline & DFC0.5 & $61.84 \pm 2.25 \mathrm{Aa}$ & $59.91 \pm 4.53 \mathrm{ABab}$ & $59.87 \pm 3.28$ Aab & $59.42 \pm 3.41 \mathrm{Aab}$ & $58.46 \pm 3.48 \mathrm{ABb}$ & $58.06 \pm 2.51 \mathrm{Ab}$ \\
\hline & $\mathrm{DFC} 1$ & $62.04 \pm 5.08 \mathrm{Aa}$ & $61.81 \pm 3.38$ Аа & $60.73 \pm 3.06^{\mathrm{Aab}}$ & $60.31 \pm 3.32 \mathrm{Aab}$ & $59.67 \pm 1.79$ Aab & $58.89 \pm 1.62 \mathrm{Ab}$ \\
\hline & $\mathrm{DFC} 2$ & $62.38 \pm 3.18 \mathrm{Aa}$ & $62.12 \pm 2.24 \mathrm{Aa}$ & $60.52 \pm 3.56^{\mathrm{Aab}}$ & $59.82 \pm 2.80 \mathrm{Ab}$ & $59.49 \pm 2.93^{\mathrm{Ab}}$ & $59.04 \pm 3.96^{\mathrm{Ab}}$ \\
\hline & SOC2 & $61.78 \pm 4.73^{\mathrm{Aa}}$ & $59.91 \pm 3.33^{\mathrm{ABab}}$ & $59.71 \pm 1.64 \mathrm{Aab}$ & $58.53 \pm 4.10^{\mathrm{ABb}}$ & $57.66 \pm 3.92 \mathrm{ABb}$ & $57.51 \pm 5.34^{\mathrm{Ab}}$ \\
\hline \multirow{6}{*}{$a^{*}$} & $\mathrm{NC}$ & $3.44 \pm 0.63^{\mathrm{a}}$ & $3.14 \pm 0.55^{\mathrm{ab}}$ & $2.93 \pm 0.97 \mathrm{abc}$ & $2.50 \pm 0.76^{b c}$ & $2.17 \pm 0.50^{\mathrm{cd}}$ & $1.37 \pm 0.50^{\mathrm{Bd}}$ \\
\hline & DFC0 & $3.53 \pm 0.50^{a}$ & $3.07 \pm 0.33^{\mathrm{ab}}$ & $3.01 \pm 0.7^{\mathrm{ab}}$ & $2.77 \pm 0.58^{b c}$ & $2.13 \pm 0.57^{\mathrm{cd}}$ & $1.62 \pm 0.49^{\mathrm{Bd}}$ \\
\hline & DFC0.5 & $3.57 \pm 0.54^{\mathrm{a}}$ & $3.10 \pm 0.55^{\mathrm{ab}}$ & $2.79 \pm 0.45^{\mathrm{ab}}$ & $2.78 \pm 0.60^{a b}$ & $2.37 \pm 0.67^{b c}$ & $1.83 \pm 0.66^{\mathrm{Bc}}$ \\
\hline & DFC1 & $3.59 \pm 0.38$ & $3.10 \pm 0.55$ & $2.82 \pm 0.65$ & $2.95 \pm 0.16$ & $2.67 \pm 0.64$ & $2.49 \pm 0.48^{\mathrm{A}}$ \\
\hline & $\mathrm{DFC} 2$ & $3.55 \pm 0.58^{a}$ & $3.35 \pm 0.69^{b}$ & $2.95 \pm 0.39 b c$ & $3.01 \pm 0.50 \mathrm{bc}$ & $2.82 \pm 0.22^{b c}$ & $2.70 \pm 0.52 \mathrm{Ac}$ \\
\hline & SOC2 & $3.58 \pm 0.68$ & $3.19 \pm 0.53$ & $2.88 \pm 0.56$ & $2.83 \pm 0.79$ & $2.71 \pm 0.66$ & $2.54 \pm 0.56^{\mathrm{A}}$ \\
\hline \multirow{6}{*}{$b^{*}$} & $\mathrm{NC}$ & $11.07 \pm 1.18^{b}$ & $11.57 \pm 2.01^{b}$ & $11.94 \pm 0.79^{b}$ & $12.28 \pm 1.36^{b}$ & $12.71 \pm 1.24^{\mathrm{ab}}$ & $14.17 \pm 1.22 \mathrm{Aa}$ \\
\hline & DFC0 & $11.05 \pm 2.04$ & $11.88 \pm 2.26$ & $12.07 \pm 0.53$ & $12.12 \pm 1.31$ & $12.41 \pm 1.99$ & $12.97 \pm 0.80 \mathrm{AB}$ \\
\hline & DFC0.5 & $11.18 \pm 2.02$ & $11.95 \pm 1.51$ & $12.14 \pm 1.63$ & $12.70 \pm 1.78$ & $12.71 \pm 1.99$ & $13.08 \pm 1.22 \mathrm{AB}$ \\
\hline & DFC1 & $10.93 \pm 2.06$ & $10.54 \pm 1.42$ & $10.97 \pm 1.25$ & $11.35 \pm 2.30$ & $11.13 \pm 2.36$ & $11.68 \pm 1.49^{\text {В }}$ \\
\hline & DFC2 & $10.81 \pm 2.19$ & $10.92 \pm 1.12$ & $11.01 \pm 2.24$ & $11.09 \pm 0.96$ & $11.11 \pm 2.37$ & $11.33 \pm 0.68^{\mathrm{B}}$ \\
\hline & SOC2 & $10.87 \pm 1.44$ & $10.70 \pm 1.97$ & $10.96 \pm 1.98$ & $11.15 \pm 1.79$ & $11.55 \pm 2.36$ & $11.84 \pm 1.94^{\text {B }}$ \\
\hline
\end{tabular}

1) NC (non-coated), DFC0 (coated with duck fat, with no chitosan), DFC0.5 (coated with duck fat and 0.5\% chitosan), DFC1 (coated with duck fat and 1\% chitosan), DFC2 (coated with duck fat and 2\% chitosan), SOC2 (coated with soybean oil and $2 \%$ chitosan). ${ }^{A-E}$ Means values in the same column are significantly different $(p<0.05) .{ }^{\text {a-e }}$ Means values in the same row are significantly different $(p<0.05)$. All values are presented as the mean \pm SD of six replicates $(n=6)$.

\subsection{Warner-Bratzler Shear Force of Coated Chicken Meat}

The WBSF values are related to the tenderness of meat samples, which is a critical organoleptic property that affects consumer preference [40]. In our study, the WBSF values of coated chicken meat were significantly affected by the presence of edible coatings (Figure 2). WBSF values gradually decreased during storage $(p<0.05)$. DFC2 exhibited the highest WBSF values during storage, whereas WBSF values were lower in the NC group than those in other groups $(p<0.05)$. This result might be attributable to the deterioration of proteins by microorganisms. The WBSF values of samples can decrease due to the degradation of proteins in meat, mainly caused by bacterial or enzymatic processes as storage progresses [41]. Thus, a higher microorganism count in NC may affect the decrease in the WBSF values of meat samples during storage. Collectively, our data suggest that the chitosan-duck fat edible coating for chicken meat can contribute to maintaining meat tenderness by inhibiting microorganisms. 


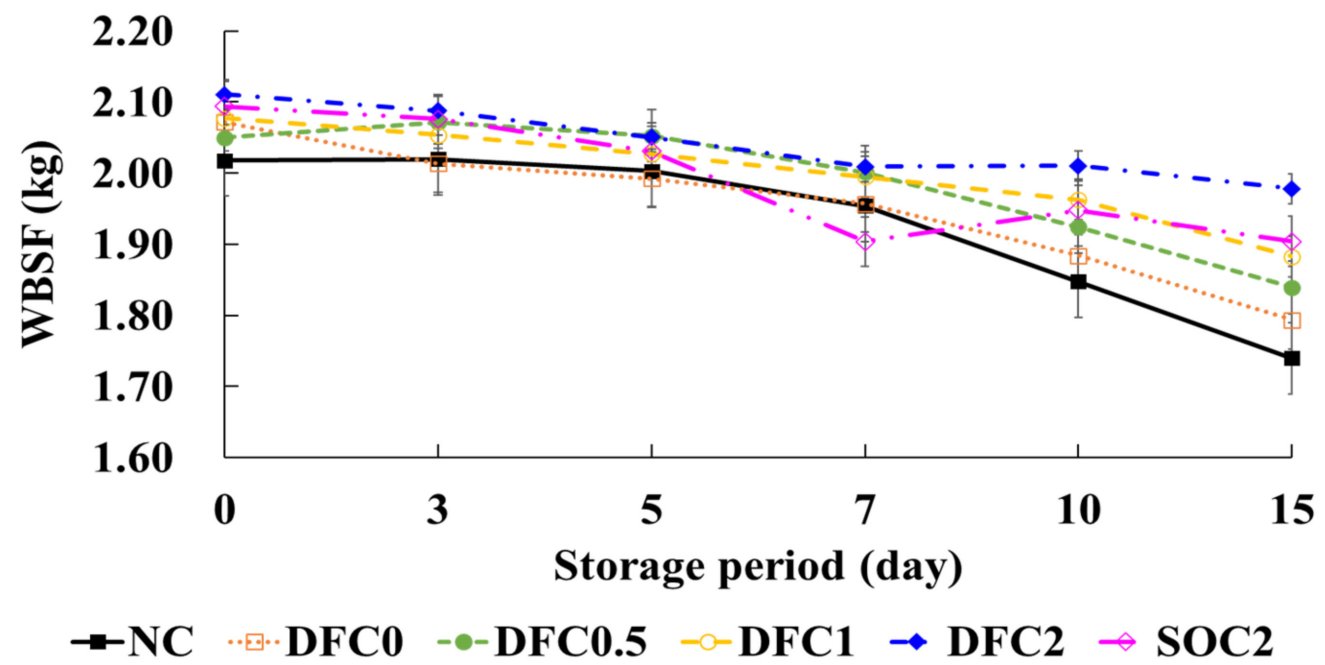

Figure 2. Warner-Bratzler shear force (WBSF) of coated chicken meat during storage at $4 \pm 1{ }^{\circ} \mathrm{C}$ for 15 days. NC, non-coated; DFC0, coated with duck fat, with no chitosan; DFC0.5, coated with duck fat and $0.5 \%$ chitosan; DFC1, coated with duck fat and $1 \%$ chitosan; DFC2, coated with duck fat and $2 \%$ chitosan; SOC2, coated with soybean oil and $2 \%$ chitosan. The error bars indicate SD $(n=3)$.

\subsection{TBARS Values and VBN of Coated Chicken Meat}

Shelf-life and the quality of meat are highly associated with lipid oxidation and protein deterioration during storage [42]. TBARS values are used for measuring the formation of secondary oxidation products, including malondialdehyde, alkenals, and alkadienals [43]. Variations in the TBARS values of the meat samples are shown in Figure 3A. The difference in TBARS values between DFC treatments and SOC2 can be explained by the fatty acid profiles of duck fat and soybean oil in the coating solution. Duck fat is more stable against lipid oxidation than soybean oil during storage because the main fatty acids in duck fat and soybean oil are oleic acid and linoleic acid, respectively [10]. The oxidative stability of oleic acid in edible oils is almost 10-times greater than that of linoleic acid [16]. Therefore, the higher resistance to oxidation of duck fat could be more suitable as an edible coating material than soybean oil.

(A)

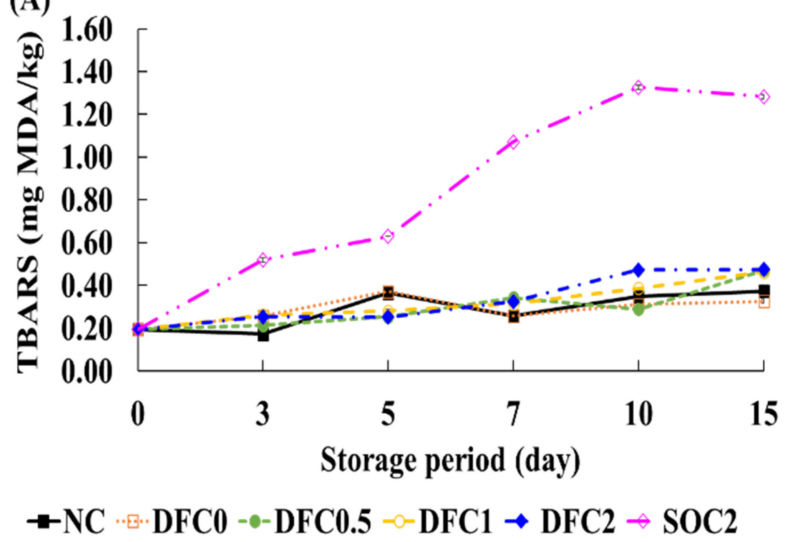

(B)

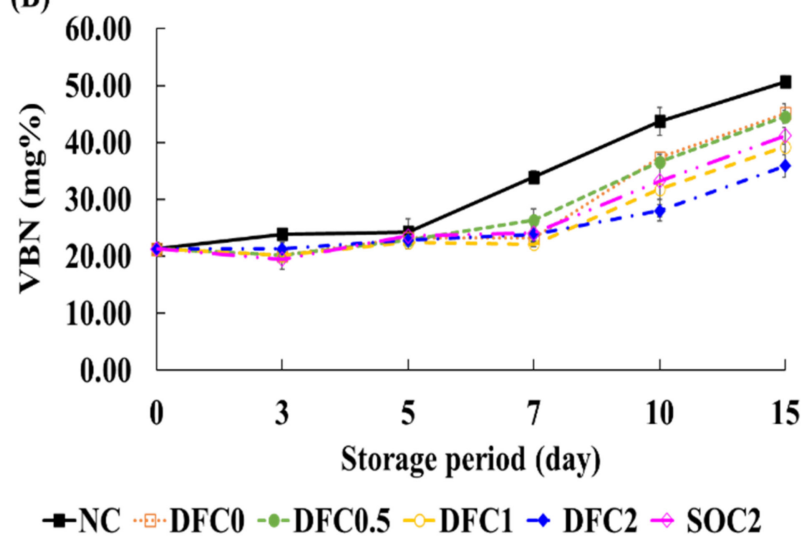

Figure 3. TBARS and VBN values of coated chicken meat during storage at $4 \pm 1^{\circ} \mathrm{C}$ for up to 15 days. (A) Thiobarbituric acid reactive substances (TBARS) and (B) volatile basic nitrogen (VBN) values were determined during storage at $4 \pm 1{ }^{\circ} \mathrm{C}$ for up to 15 days. NC, non-coated; DFC0, coated with duck fat, with no chitosan; DFC0.5, coated with duck fat and $0.5 \%$ chitosan; DFC1, coated with duck fat and $1 \%$ chitosan; DFC2, coated with duck fat and $2 \%$ chitosan; SOC2, coated with soybean oil and $2 \%$ chitosan. The error bars indicate SD $(n=3)$. 
The VBN value is an important indicator of protein deterioration in meat and meat products [44]. VBN mainly includes ammonia and primary, secondary, and tertiary amines. In general, the VBN value is an indicator of meat spoilage, particularly when it exceeds $25 \mathrm{mg} \%$ [34]. The VBN data of the chicken meat samples during storage are presented in Figure 3B. VBN values for all samples increased during storage $(p<0.05)$, while DFC2 had significantly lower VBN values among all groups $(p<0.05)$. The VBN values of most samples were over the standard point $(25 \mathrm{mg} \%$ ) on day 10, while DFC2 showed VBN values over the standard point $(25 \mathrm{mg} \%)$ on day 15 . The increase in VBN is related to the hydrolysis of proteins to amino acids, peptides, biogenic amines, inorganic nitrogen, and the increasing contents of volatile bases due to enzymes and microorganisms during storage [45]. Thus, lower microbial growth might be expected in the DFC groups, particularly in the DFC2 group.

\subsection{Growth of Microorganisms on Coated Chicken Meat}

The results of TVC, E. coli, coliforms, Listeria spp., molds, and yeasts are shown in Table 2. Meat decay is generally defined when the TVC exceeds 7 log CFU/g [46]. The TVC of DFC2 was significantly lower than that of other groups during storage $(p<0.05)$, and only DFC2 did not exceed the standard point for meat spoilage until the end of the storage period. The abundance of E. coli and coliforms are important hygienic quality indicators for meat and meat products [47]. The microbial counts increased during storage in all groups, and the rate of this increase was significantly lower in DFC2 than that in NC after 15 days of storage. The meat and meat product surfaces are considerably susceptible to mold and yeast growth, which are related to spoilage and have negative effects on organoleptic properties and safety [34]. At the beginning of storage, mold and yeast were not detected in any sample. After 3 days, mold and yeast were detected in all samples, with NC showing the highest counts of mold and yeast at the end of storage $(p<0.05)$. DFC2 showed significantly higher growth inhibitory effects against mold and yeast during storage $(p<0.05)$. Listeria spp. are foodborne pathogens in meat and meat products and have increasingly proliferated despite improvements in control measures [48]. Listeria spp. were not detected in any samples until day 3, whereas this pathogen was detected on day 5 only in DFC0 and DFC0.5. Meanwhile, Listeria spp. were not detected in DFC2 and SOC2 until the end of storage. These data indicate that chitosan inhibits Listeria spp. Overall, DFC2 showed the highest antimicrobial activities against TVC, E. coli, coliforms, Listeria spp., molds, and yeasts during storage. This was due to the strong antimicrobial properties of chitosan. Previous studies have shown that edible coatings with chitosan can inhibit microorganisms in meat and meat products [22,49]. Overall, the $2 \%$ chitosan-added duck fat edible coating can improve the shelf-life of chicken meat by inhibiting the growth of microorganisms during refrigerated storage. 
Table 2. Microorganisms in coated chicken meat during storage at $4 \pm 1{ }^{\circ} \mathrm{C}$ for up to 15 days.

\begin{tabular}{|c|c|c|c|c|c|c|c|}
\hline \multirow{2}{*}{$\begin{array}{l}\text { Parameter } \\
\text { (Log CFU/g) }\end{array}$} & \multirow{2}{*}{ Treatment $^{1)}$} & \multicolumn{6}{|c|}{ Storage Period (Day) } \\
\hline & & 0 & 3 & 5 & 7 & 10 & 15 \\
\hline \multirow{6}{*}{ TVC } & $\mathrm{NC}$ & $3.52 \pm 0.06^{\mathrm{e}}$ & $5.43 \pm 0.11^{\mathrm{BCd}}$ & $6.78 \pm 0.04^{\mathrm{Bc}}$ & $8.71 \pm 0.02 \mathrm{Aa}$ & $8.66 \pm 0.05$ Аa & $8.15 \pm 0.01 \mathrm{Ab}$ \\
\hline & $\mathrm{DFC} 0$ & $3.52 \pm 0.06^{\mathrm{e}}$ & $5.97 \pm 0.02 \mathrm{Ad}$ & $6.81 \pm 0.05^{\mathrm{Bc}}$ & $7.62 \pm 0.02^{\mathrm{Bb}}$ & $8.39 \pm 0.22 \mathrm{Ba}$ & $8.24 \pm 0.05 \mathrm{Aa}$ \\
\hline & DFC0.5 & $3.52 \pm 0.06^{\mathrm{f}}$ & $5.67 \pm 0.02 \mathrm{ABe}$ & $7.83 \pm 0.02 \mathrm{Ad}$ & $6.66 \pm 0.26^{\mathrm{Cc}}$ & $7.46 \pm 0.09 \mathrm{Cb}$ & $8.18 \pm 0.04 \mathrm{Aa}$ \\
\hline & DFC1 & $3.52 \pm 0.06^{\mathrm{e}}$ & $5.32 \pm 0.28 \mathrm{Cd}$ & $5.13 \pm 0.02 \mathrm{Dd}$ & $6.50 \pm 0.01 \mathrm{Cc}$ & $7.66 \pm 0.03 \mathrm{Ca}$ & $6.93 \pm 0.04^{\mathrm{Bb}}$ \\
\hline & $\mathrm{DFC} 2$ & $3.52 \pm 0.06^{c}$ & $4.10 \pm 0.17 \mathrm{Db}$ & $4.02 \pm 0.03 \mathrm{~Eb}$ & $4.24 \pm 0.34 \mathrm{~Eb}$ & $6.32 \pm 0.02 \mathrm{Ea}$ & $6.15 \pm 0.21 \mathrm{Ca}$ \\
\hline & SOC2 & $3.52 \pm 0.06^{\mathrm{f}}$ & $5.24 \pm 0.06^{\mathrm{BCd}}$ & $5.48 \pm 0.01 \mathrm{Cc}$ & $4.85 \pm 0.01 \mathrm{De}$ & $7.14 \pm 0.04 \mathrm{Da}$ & $6.78 \pm 0.01^{\mathrm{Bb}}$ \\
\hline \multirow{6}{*}{ E. coli } & NC & $3.19 \pm 0.06^{\mathrm{e}}$ & $3.72 \pm 0.34 \mathrm{ABd}$ & $4.18 \pm 0.07^{\mathrm{Bc}}$ & $5.23 \pm 0.12^{\mathrm{Bb}}$ & $7.98 \pm 0.04^{\mathrm{Aa}}$ & $7.85 \pm 0.09^{\mathrm{Ba}}$ \\
\hline & DFC0 & $3.19 \pm 0.06^{\mathrm{f}}$ & $3.93 \pm 0.04 \mathrm{Ae}$ & $4.57 \pm 0.10 \mathrm{Ad}$ & $6.24 \pm 0.02 \mathrm{Ac}$ & $7.90 \pm 0.02 \mathrm{Ab}$ & $8.11 \pm 0.06 \mathrm{Aa}$ \\
\hline & DFC0.5 & $3.19 \pm 0.06^{\mathrm{e}}$ & $3.91 \pm 0.19 \mathrm{Ad}$ & $3.83 \pm 0.09 \mathrm{Dd}$ & $4.71 \pm 0.10 \mathrm{Cc}$ & $6.49 \pm 0.02^{\mathrm{Bb}}$ & $7.49 \pm 0.02 \mathrm{Ca}$ \\
\hline & DFC1 & $3.19 \pm 0.06^{\mathrm{e}}$ & $3.54 \pm 0.09 \mathrm{ABCd}$ & $3.92 \pm 0.11 \mathrm{CDc}$ & $4.07 \pm 0.16^{\mathrm{Dc}}$ & $6.58 \pm 0.01 \mathrm{Ba}$ & $6.32 \pm 0.09 \mathrm{~Eb}$ \\
\hline & $\mathrm{DFC} 2$ & $3.19 \pm 0.06^{\mathrm{d}}$ & $3.20 \pm 0.01 \mathrm{Ccd}$ & $3.35 \pm 0.01 \mathrm{Ecd}$ & $3.39 \pm 0.12$ Ec & $4.36 \pm 0.12^{\mathrm{Db}}$ & $5.10 \pm 0.04 \mathrm{Fa}$ \\
\hline & SOC2 & $3.19 \pm 0.06^{\mathrm{e}}$ & $3.48 \pm 0.01 \mathrm{BCd}$ & $4.07 \pm 0.01 \mathrm{BCc}$ & $3.93 \pm 0.21 \mathrm{Dc}$ & $4.68 \pm 0.06 \mathrm{Cb}$ & $7.30 \pm 0.06^{\mathrm{Da}}$ \\
\hline \multirow{6}{*}{ Coliform } & $\mathrm{NC}$ & $3.10 \pm 0.01^{\mathrm{e}}$ & $3.72 \pm 0.34 \mathrm{ABd}$ & $4.15 \pm 0.02^{\mathrm{Bc}}$ & $5.19 \pm 0.06^{\mathrm{Bb}}$ & $7.95 \pm 0.06^{\mathrm{Aa}}$ & $7.83 \pm 0.08^{\mathrm{Ba}}$ \\
\hline & $\mathrm{DFC} 0$ & $3.10 \pm 0.01^{\mathrm{f}}$ & $4.16 \pm 0.02 \mathrm{Ae}$ & $4.71 \pm 0.04 \mathrm{Ad}$ & $6.13 \pm 0.07 \mathrm{Ac}$ & $7.95 \pm 0.03^{\mathrm{Ab}}$ & $8.08 \pm 0.02 \mathrm{Aa}$ \\
\hline & DFC0.5 & $3.10 \pm 0.01^{\mathrm{e}}$ & $3.80+0.14 \mathrm{Ad}$ & $3.86+0.01 \mathrm{Cd}$ & $4.69+0.03 \mathrm{Cc}$ & $6.41+0.05^{\mathrm{Bb}}$ & $7.42+0.17 \mathrm{Ca}$ \\
\hline & DFC1 & $3.10 \pm 0.01^{\mathrm{f}}$ & $3.81 \pm 0.05^{\mathrm{Ae}}$ & $3.93 \pm 0.07^{\mathrm{Cd}}$ & $4.18 \pm 0.01^{\mathrm{Dc}}$ & $6.57 \pm 0.01^{\mathrm{Ba}}$ & $6.36 \pm 0.05^{\mathrm{Db}}$ \\
\hline & DFC2 & $3.10 \pm 0.01^{c}$ & $3.15 \pm 0.21 \mathrm{Bc}$ & $3.41 \pm 0.01 \mathrm{Dc}$ & $3.24 \pm 0.34 \mathrm{Ec}$ & $4.16 \pm 0.17^{\mathrm{Db}}$ & $5.14 \pm 0.02 \mathrm{Ea}$ \\
\hline & SOC2 & $3.10 \pm 0.01^{d}$ & $3.76 \pm 0.40 \mathrm{Ac}$ & $4.13 \pm 0.01^{\mathrm{Bc}}$ & $3.78 \pm 0.25^{\mathrm{Dc}}$ & $4.76 \pm 0.01 \mathrm{Cb}$ & $7.41 \pm 0.05 \mathrm{Ca}$ \\
\hline \multirow{6}{*}{$\begin{array}{l}\text { Yeast and } \\
\text { molds }\end{array}$} & $\mathrm{NC}$ & N.D. & $1.00 \pm 0.10^{\mathrm{Cc}}$ & $3.77 \pm 0.04 \mathrm{Ab}$ & $4.17 \pm 0.01$ Aab & $4.75 \pm 0.01$ Aab & $5.47 \pm 0.03 \mathrm{Aa}$ \\
\hline & DFC0 & N.D. & $3.04 \pm 0.01 \mathrm{Ad}$ & $3.88 \pm 0.02 \mathrm{Ac}$ & $3.85 \pm 0.01^{\mathrm{Bc}}$ & $4.95 \pm 0.07^{\mathrm{Ab}}$ & $5.32 \pm 0.03^{\mathrm{Ba}}$ \\
\hline & DFC0.5 & N.D. & $2.15 \pm 0.21 \mathrm{BC}$ & $3.63 \pm 0.19 \mathrm{Ab}$ & $3.66 \pm 0.26^{\mathrm{BCb}}$ & $3.69 \pm 0.30^{\mathrm{Cb}}$ & $4.65 \pm 0.03 \mathrm{Ca}$ \\
\hline & DFC1 & N.D. & $2.24 \pm 0.34^{\mathrm{Bc}}$ & $3.55 \pm 0.03^{\mathrm{Ab}}$ & $3.86 \pm 0.06^{\mathrm{Bb}}$ & $4.24 \pm 0.05^{\mathrm{Ba}}$ & $4.50 \pm 0.03 \mathrm{Da}$ \\
\hline & DFC2 & N.D. & $1.15 \pm 0.36^{\mathrm{Cb}}$ & $2.35 \pm 0.49^{\mathrm{Bab}}$ & $2.39 \pm 0.12^{\mathrm{Dab}}$ & $3.57 \pm 0.05 \mathrm{Ca}$ & $3.77 \pm 0.03 \mathrm{Fa}$ \\
\hline & SOC2 & N.D. & $2.60 \pm 0.01 \mathrm{Bd}$ & $3.78 \pm 0.04 \mathrm{Ab}$ & $3.41 \pm 0.02 \mathrm{Cc}$ & $3.82 \pm 0.02 \mathrm{Cb}$ & $4.01 \pm 0.01$ Ea \\
\hline \multirow{6}{*}{ Listeria spp. } & $\mathrm{NC}$ & N.D. & N.D. & N.D. & $2.81 \pm 0.47^{\mathrm{Ab}}$ & $2.39 \pm 0.12 \mathrm{Ab}$ & $4.12 \pm 0.23^{\mathrm{Aa}}$ \\
\hline & DFC0 & N.D. & N.D. & $2.48 \pm 0.01^{\mathrm{Ab}}$ & $2.94 \pm 0.34 \mathrm{Aab}$ & $2.82 \pm 0.31 \mathrm{Ab}$ & $3.35 \pm 0.16^{\mathrm{Ba}}$ \\
\hline & DFC0.5 & N.D. & N.D. & $1.00 \pm 0.10^{\mathrm{Bbc}}$ & $3.38 \pm 0.33^{\mathrm{Aa}}$ & $2.15 \pm 0.21$ Aab & $3.35 \pm 0.49 \mathrm{Ba}$ \\
\hline & DFC1 & N.D. & N.D. & N.D. & N.D. & $1.24 \pm 0.15^{\mathrm{ABb}}$ & $3.93 \pm 0.04 \mathrm{ABa}$ \\
\hline & DFC2 & N.D. & N.D. & N.D. & N.D. & N.D. & N.D. \\
\hline & SOC2 & N.D. & N.D. & N.D. & N.D. & N.D. & N.D. \\
\hline
\end{tabular}

1) NC (non-coated), DFC0 (coated with duck fat, with no chitosan), DFC0.5 (coated with duck fat and $0.5 \%$ chitosan), DFC1 (coated with duck fat and 1\% chitosan), DFC2 (coated with duck fat and $2 \%$ chitosan), SOC2 (coated with soybean oil and $2 \%$ chitosan). ${ }^{A-E}$ Means values in the same column are significantly different $(p<0.05) .{ }^{\text {a-f }}$ Means values in the same row are significantly different $(p<0.05)$. All values are presented as the mean \pm SD of three replicates $(n=3)$.

\section{Conclusions}

In this study, the effects of chitosan and duck fat-based emulsion coating on the quality characteristics and microbial stability of chicken breast meat were investigated. The duck fat-based coating solution showed higher apparent viscosity than that of the soybean oil-based coating solution, which resulted in a high coating rate for chicken meat. The physicochemical properties, including $\mathrm{pH}$, color, and WBSF value of the DFC2 group (chicken meat coated with duck fat and $2 \%$ chitosan) improved significantly compared to those of other groups $(p<0.05)$. The DFC2 group showed lower lipid oxidation (TBARS value) and protein deterioration (VBN value) during refrigerated storage over 15 days. Furthermore, DFC2 was effective at inhibiting the growth of microorganisms, including TVC, E. coli, coliforms, Listeria spp., molds, and yeasts during storage. Lower lipid oxidation and protein deterioration in DFC2 were owing to the higher apparent viscosity and coating rate in duck fat compared to soybean oil. Here, the higher viscosity and coating rate in DFC2 were probably due to the higher melting point of duck fat. In addition, the higher coating rate of DFC2 made more chitosan concentrations on the coated samples and that resulted in the extending shelf-life of chicken meat. Our data suggest that chitosan/duck fat-based edible coatings can be used to maintain the quality of raw chicken meat during refrigeration. This edible coating solution could be further studied regarding the sensory 
properties of coated products and its application in a variety of foods, such as meat products, vegetables, and fruits.

Author Contributions: Conceptualization, D.-M.S. and S.-G.H. (Sung-Gu Han); formal analysis, D.-M.S.; investigation, D.-M.S., J.-H.Y., Y.-J.K., D.-H.K., H.-C.K., H.S., S.-G.H. (Seo-Gu Han), J.-H.H. and S.-J.L.; writing-original draft preparation, D.-M.S.; writing-review and editing, Y.-J.K. and S.-G.H. (Sung-Gu Han), supervision, S.-G.H. (Sung-Gu Han). All authors have read and agreed to the published version of the manuscript.

Funding: This paper was supported by Konkuk University Researcher Fund in 2021.

Institutional Review Board Statement: Not applicable.

Informed Consent Statement: Not applicable.

Data Availability Statement: Data is contained within the article.

Conflicts of Interest: The authors declare no conflict of interest.

\section{References}

1. Latou, E.; Mexis, S.; Badeka, A.; Kontakos, S.; Kontominas, M. Combined effect of chitosan and modified atmosphere packaging for shelf life extension of chicken breast fillets. LWT_Food Sci. Technol. 2014, 55, 263-268. [CrossRef]

2. Anang, D.; Rusul, G.; Bakar, J.; Ling, F.H. Effects of lactic acid and lauricidin on the survival of Listeria monocytogenes, Salmonella enteritidis and Escherichia coli O157: H7 in chicken breast stored at 4 C. Food Control 2007, 18, 961-969. [CrossRef]

3. Langroodi, A.M.; Tajik, H.; Mehdizadeh, T.; Moradi, M.; Kia, E.M.; Mahmoudian, A. Effects of sumac extract dipping and chitosan coating enriched with Zataria multiflora Boiss oil on the shelf-life of meat in modified atmosphere packaging. LWT_Food Sci. Technol. 2018, 98, 372-380. [CrossRef]

4. Bravin, B.; Peressini, D.; Sensidoni, A. Development and application of polysaccharide-lipid edible coating to extend shelf-life of dry bakery products. J. Food Eng. 2006, 76, 280-290. [CrossRef]

5. Xiong, Y.; Kamboj, M.; Ajlouni, S.; Fang, Z. Incorporation of salmon bone gelatine with chitosan, gallic acid and clove oil as edible coating for the cold storage of fresh salmon fillet. Food Control 2021, 125, 107994. [CrossRef]

6. Yousuf, B.; Sun, Y.; Wu, S. Lipid and Lipid-containing Composite Edible Coatings and Films. Food Rev. Int. 2021, 1-24. [CrossRef]

7. Ren, K.; Fei, T.; Metzger, K.; Wang, T. Coating performance and rheological characteristics of novel soybean oil-based wax emulsions. Ind. Crops Prod. 2019, 140, 111654. [CrossRef]

8. Lehtinen, O.-P.; Nugroho, R.W.N.; Lehtimaa, T.; Vierros, S.; Hiekkataipale, P.; Ruokolainen, J.; Sammalkorpi, M.; Österberg, M. Effect of temperature, water content and free fatty acid on reverse micelle formation of phospholipids in vegetable oil. Colloids Surf. B Biointerfaces 2017, 160, 355-363. [CrossRef]

9. Vargas, M.; Albors, A.; Chiralt, A. Application of chitosan-sunflower oil edible films to pork meat hamburgers. Procedia Food Sci. 2011, 1, 39-43. [CrossRef]

10. Shin, D.-M.; Yune, J.H.; Kim, T.-K.; Kim, Y.J.; Kwon, H.C.; Jeong, C.H.; Choi, Y.-S.; Han, S.G. Physicochemical properties and oxidative stability of duck fat-added margarine for reducing the use of fully hydrogenated soybean oil. Food Chem. 2021, 363, 130260. [CrossRef]

11. Qiao, Y.; Huang, J.; Chen, Y.; Chen, H.; Zhao, L.; Huang, M.; Zhou, G. Meat quality, fatty acid composition and sensory evaluation of Cherry Valley, Spent Layer and Crossbred ducks. Anim. Sci. J. 2017, 88, 156-165. [CrossRef]

12. Gong, Y.; Weber, P.F.; Richards, M.P. Characterizing quality of rendered duck fat compared to other fats and oils. J. Food Qual. 2007, 30, 169-186. [CrossRef]

13. Shin, D.-M.; Do Hyun Kim, J.H.Y.; Kwon, H.C.; Kim, H.J.; Seo, H.G.; Han, S.G. Oxidative stability and quality characteristics of duck, chicken, swine and bovine skin fats extracted by pressurized hot water extraction. Food Sci. Anim. Resour. 2019, $39,446$. [CrossRef]

14. Kang, E.S.; Kim, H.J.; Han, S.G.; Seo, H.G. Duck oil-loaded nanoemulsion inhibits senescence of angiotensin II-treated vascular smooth muscle cells by upregulating SIRT1. Food Sci. Anim. Resour. 2020, 40, 106. [CrossRef]

15. Ros, E. Health benefits of nut consumption. Nutrients 2010, 2, 652-682. [CrossRef]

16. Nawade, B.; Mishra, G.P.; Radhakrishnan, T.; Dodia, S.M.; Ahmad, S.; Kumar, A.; Kumar, A.; Kundu, R. High oleic peanut breeding: Achievements, perspectives, and prospects. Trends Food Sci. Technol. 2018, 78, 107-119. [CrossRef]

17. Taqi, A.; Askar, K.A.; Nagy, K.; Mutihac, L.; Stamatin, L. Effect of different concentrations of olive oil and oleic acid on the mechanical properties of albumen (egg white) edible films. Afr. J. Biotechnol. 2011, 10, 12963-12972.

18. Ray, C.L.; Gawenis, J.A.; Greenlief, C.M. A New Method for Olive Oil Screening Using Multivariate Analysis of Proton NMR Spectra. Molecules 2022, 27, 213. [CrossRef]

19. Umaraw, P.; Verma, A.K. Comprehensive review on application of edible film on meat and meat products: An eco-friendly approach. Crit. Rev. Food Sci. Nutr. 2017, 57, 1270-1279. [CrossRef] 
20. Kumarihami, H.P.C.; Kim, Y.-H.; Kwack, Y.-B.; Kim, J.; Kim, J.G. Application of chitosan as edible coating to enhance storability and fruit quality of Kiwifruit: A Review. Sci. Hortic. 2022, 292, 110647. [CrossRef]

21. Yüksel, Ç.; Atalay, D.; Erge, H.S. The effects of chitosan coating and vacuum packaging on quality of fresh-cut pumpkin slices during storage. J. Food Processing Preserv. 2022, e16365. [CrossRef]

22. Hassanzadeh, P.; Tajik, H.; Rohani, S.M.R.; Moradi, M.; Hashemi, M.; Aliakbarlu, J. Effect of functional chitosan coating and gamma irradiation on the shelf-life of chicken meat during refrigerated storage. Radiat. Phys. Chem. 2017, 141, 103-109. [CrossRef]

23. Xiong, Y.; Chen, M.; Warner, R.D.; Fang, Z. Incorporating nisin and grape seed extract in chitosan-gelatine edible coating and its effect on cold storage of fresh pork. Food Control 2020, 110, 107018. [CrossRef]

24. Jasour, M.S.; Ehsani, A.; Mehryar, L.; Naghibi, S.S. Chitosan coating incorporated with the lactoperoxidase system: An active edible coating for fish preservation. J. Sci. Food Agric. 2015, 95, 1373-1378. [CrossRef] [PubMed]

25. Wardy, W.; Torrico, D.D.; Jirangrat, W.; No, H.K.; Saalia, F.K.; Prinyawiwatkul, W. Chitosan-soybean oil emulsion coating affects physico-functional and sensory quality of eggs during storage. LWT_Food Sci. Technol. 2011, 44, 2349-2355. [CrossRef]

26. Sathivel, S. Chitosan and protein coatings affect yield, moisture loss, and lipid oxidation of pink salmon (Oncorhynchus gorbuscha) fillets during frozen storage. J. Food Sci. 2005, 70, e455-e459. [CrossRef]

27. Shin, D.-M.; Hwang, K.-E.; Lee, C.-W.; Kim, T.-K.; Park, Y.-S.; Han, S.G. Effect of Swiss chard (Beta vulgaris var. cicla) as nitrite replacement on color stability and shelf-life of cooked pork patties during refrigerated storage. Food Sci. Anim. Resour. 2017, 37, 418. [CrossRef] [PubMed]

28. Kim, T.-K.; Hwang, K.-E.; Lee, M.-A.; Paik, H.-D.; Kim, Y.-B.; Choi, Y.-S. Quality characteristics of pork loin cured with green nitrite source and some organic acids. Meat Sci. 2019, 152, 141-145. [CrossRef]

29. Hwang, J.-K.; Shin, H.-H. Rheological properties of chitosan solutions. Korea-Aust. Rheol. J. 2000, 12, 175-179.

30. Park, S.-Y.; Kim, H.-Y. Fried pork loin batter quality with the addition of various dietary fibers. J. Anim. Sci. Technol. 2021, 63, 137. [CrossRef]

31. Abdul-Hamid, A.; Luan, Y.S. Functional properties of dietary fibre prepared from defatted rice bran. Food Chem. 2000, 68, 15-19. [CrossRef]

32. Liu, L.; Wang, B.; Gao, Y.; Bai, T.-c. Chitosan fibers enhanced gellan gum hydrogels with superior mechanical properties and water-holding capacity. Carbohydr. Polym. 2013, 97, 152-158. [CrossRef] [PubMed]

33. Tsafrakidou, P.; Sameli, N.; Bosnea, L.; Chorianopoulos, N.; Samelis, J. Assessment of the spoilage microbiota in minced free-range chicken meat during storage at $4 \mathrm{C}$ in retail modified atmosphere packages. Food Microbiol. 2021, 99, 103822. [CrossRef]

34. Yaghoubi, M.; Ayaseh, A.; Alirezalu, K.; Nemati, Z.; Pateiro, M.; Lorenzo, J.M. Effect of chitosan coating incorporated with Artemisia fragrans essential oil on fresh chicken meat during refrigerated storage. Polymers 2021, 13, 716. [CrossRef] [PubMed]

35. Liu, F.; Chang, W.; Chen, M.; Xu, F.; Ma, J.; Zhong, F. Tailoring physicochemical properties of chitosan films and their protective effects on meat by varying drying temperature. Carbohydr. Polym. 2019, 212, 150-159. [CrossRef]

36. Kuswandi, B.; Nurfawaidi, A. On-package dual sensors label based on $\mathrm{pH}$ indicators for real-time monitoring of beef freshness. Food Control 2017, 82, 91-100. [CrossRef]

37. Noori, S.; Zeynali, F.; Almasi, H. Antimicrobial and antioxidant efficiency of nanoemulsion-based edible coating containing ginger (Zingiber officinale) essential oil and its effect on safety and quality attributes of chicken breast fillets. Food Control 2018, 84, 312-320. [CrossRef]

38. Seideman, S.; Cross, H.; Smith, G.; Durland, P. Factors associated with fresh meat color: A review. J. Food Qual. 1984, 6, 211-237. [CrossRef]

39. Zhang, H.; He, P.; Kang, H.; Li, X. Antioxidant and antimicrobial effects of edible coating based on chitosan and bamboo vinegar in ready to cook pork chops. LWT-Food Sci. Technol. 2018, 93, 470-476. [CrossRef]

40. Yu, L.; Lee, E.; Jeong, J.; Paik, H.; Choi, J.; Kim, C. Effects of thawing temperature on the physicochemical properties of pre-rigor frozen chicken breast and leg muscles. Meat Sci. 2005, 71, 375-382. [CrossRef]

41. Sujiwo, J.; Kim, D.; Jang, A. Relation among quality traits of chicken breast meat during cold storage: Correlations between freshness traits and torrymeter values. Poult. Sci. 2018, 97, 2887-2894. [CrossRef]

42. Domínguez, R.; Pateiro, M.; Gagaoua, M.; Barba, F.J.; Zhang, W.; Lorenzo, J.M. A comprehensive review on lipid oxidation in meat and meat products. Antioxidants 2019, 8, 429. [CrossRef] [PubMed]

43. Shahidi, F.; Desilva, C.; Amarowicz, R. Antioxidant activity of extracts of defatted seeds of niger (Guizotia abyssinica). J. Am. Oil Chem. Soc. 2003, 80, 443-450. [CrossRef]

44. Rezaei, F.; Shahbazi, Y. Shelf-life extension and quality attributes of sauced silver carp fillet: A comparison among direct addition, edible coating and biodegradable film. LWT_Food Sci. Technol. 2018, 87, 122-133. [CrossRef]

45. Yu, H.H.; Kim, Y.J.; Park, Y.J.; Shin, D.-M.; Choi, Y.-S.; Lee, N.-K.; Paik, H.-D. Application of mixed natural preservatives to improve the quality of vacuum skin packaged beef during refrigerated storage. Meat Sci. 2020, 169, 108219. [CrossRef] [PubMed]

46. Peng, Y.; Zhang, J.; Wang, W.; Li, Y.; Wu, J.; Huang, H.; Gao, X.; Jiang, W. Potential prediction of the microbial spoilage of beef using spatially resolved hyperspectral scattering profiles. J. Food Eng. 2011, 102, 163-169. [CrossRef]

47. Lorenzo, J.M.; Munekata, P.E.; Dominguez, R.; Pateiro, M.; Saraiva, J.A.; Franco, D. Main groups of microorganisms of relevance for food safety and stability: General aspects and overall description. In Innovative Technologies for Food Preservation; Elsevier: Amsterdam, The Netherlands, 2018; pp. 53-107. 
48. Zwirzitz, B.; Wetzels, S.U.; Dixon, E.D.; Fleischmann, S.; Selberherr, E.; Thalguter, S.; Quijada, N.M.; Dzieciol, M.; Wagner, M.; Stessl, B. Co-occurrence of Listeria spp. and spoilage associated microbiota during meat processing due to cross-contamination events. Front. Microbiol. 2021, 12, 632935. [CrossRef] [PubMed]

49. Kanatt, S.R.; Rao, M.; Chawla, S.; Sharma, A. Effects of chitosan coating on shelf-life of ready-to-cook meat products during chilled storage. LWT-Food Sci. Technol. 2013, 53, 321-326. [CrossRef] 